AL-MARSHAD: JURNAL ASTRONOMI ISLAM DAN ILMU-ILMU BERKAITAN

ISSN 2442-5729 (print) || ISSN 2598-2559 (online)

http://jurnal.umsu.ac.id/index.php/almarshad

DOI: 10.30596/jam.v5i1.3121 || Vol. 5, No. 1 Juni 2019

\title{
Pemanfaatan Metode Moving Average dalam Menentukan Awal Waktu Salat Subuh Menggunakan Sky Quality Meter (SQM)
}

\author{
Abu Yazid Raisal ${ }^{1 *}$, Yudhiakto Pramudya ${ }^{2}$, Okimustava $^{3}$, Muchlas $^{4}$ \\ Universitas Ahmad Dahlan 1,2,3,4 \\ "1 email: abuyazidraisal@gmail.com \\ 2 email: ypramudya.uad@gmail.com \\ 3 email: okimustava@pfis.uad.ac.id \\ ${ }^{4}$ email: muchlas.te@uad.ac.id
}

\begin{tabular}{|c|c|}
\hline Abstract & Artikel Info \\
\hline $\begin{array}{l}\text { The beginning of prayer time is important for Muslims because } \\
\text { Islam advocates for prayer at the beginning of time. The } \\
\text { beginning of Zuhr, Asar and Maghrib prayer times can be done by } \\
\text { looking position of the Sun directly. However, the position of the } \\
\text { sun cannot be directly observed to determine the beginning of the } \\
\text { Fajr and Isha prayer times, because the Sun is below the horizon. } \\
\text { The beginning of the Fajr prayer time can be determined by } \\
\text { measuring sky brightness using the Sky Quality Meter (SQM). } \\
\text { Many factors can affect SQM in collecting light so that the data is } \\
\text { not separated from noise. The use of the moving average method } \\
\text { reduces noise, making it easier to determine the beginning of the } \\
\text { Fajr prayer time using SQM. } \\
\text { Keyword: Fajr Time, Moving Average, Sky Quality Meter }\end{array}$ & $\begin{array}{c}\text { Received: } \\
\text { 15 Januari } 2019 \\
\text { Revised: } \\
\text { 13 Februari } 2019 \\
\text { Accepted: } \\
\text { 20 April 2019 } \\
\text { Published: } \\
\text { 02 Juni } 2019\end{array}$ \\
\hline Abstrak & \\
\hline $\begin{array}{l}\text { Awal waktu salat merupakan hal yang penting bagi umat Islam } \\
\text { karena Islam menganjurkan untuk mengerjakan salat wajib diawal } \\
\text { waktu. Awal waktu salat Zuhur, Asar, dan Maghrib dapat } \\
\text { dilakukan dengan melihat posisi Matahari secara langsung. } \\
\text { Namun, awal waktu salat Subuh dan isya tidak dapat dilakukan } \\
\text { pengamatan posisi Matahari secara langsung karena Matahari } \\
\text { berada di bawah horizon. Awal waktu salat Subuh dapat } \\
\text { ditentukan dengan mengukur kecerahan langit menggunakan Sky } \\
\text { Quality Meter (SQM). Banyak faktor yang mempengaruhi SQM } \\
\text { dalam pengumpulan cahaya sehingga data tidak terlepas dari } \\
\text { noise. Penggunaan metode moving average mengurangi noise } \\
\text { sehingga memudahkan dalam menentukan awal waktu salat } \\
\text { Subuh menggunakan SQM. } \\
\text { Kata Kunci: Waktu Subuh, Moving Average, Sky Quality Meter }\end{array}$ & \\
\hline
\end{tabular}

\section{A. Pendahuluan}

Setiap hari umat islam diwajibkan untuk melaksanakan salat fardu lima waktu yaitu Subuh, Zuhur, Asar,
Maghrib, dan Isya. Dalam menunaikan kewajiban ibadah salat fardu, umat islam tidak bisa memilih waktu seperti yang dikehendakinya. Salat tidak 


\section{AL-MARSHAD: JURNAL ASTRONOMI ISLAM DAN ILMU-ILMU BERKAITAN \\ ISSN 2442-5729 (print) || ISSN 2598-2559 (online) \\ http://jurnal.umsu.ac.id/index.php/almarshad \\ DOI: 10.30596/jam.v5i1.3121 || Vol. 5, No. 1 Juni 2019}

dikerjakan saat umat islam memiliki waktu luang akan tetapi umat islam harus meluangkan waktu untuk mengerjakan salat bila waktunya telah tiba, karena salat telah terikat dengan waktu-waktu yang telah ditentukan ${ }^{1}$ (Ismail, 2015). Waktu salat fardu tersebut sudah ditentukan dalam alquran dan hadis. Awal waktu salat merupakan hal yang penting dalam ibadah bagi umat Islam karena Islam menganjurkan untuk mengerjakan salat wajib diawal waktu.

Waktu salat ditentukan berdasarkan kedudukan Matahari terhadap bumi. Waktu salat zuhur ditandai dengan tergelincirnya Matahari dari posisi kulminasi atas. Waktu salat Asar ditandai ketika bayang-bayang suatu benda sama panjang, waktu salat Maghrib dimulai ketika Matahari telah terbenam, waktu salat Isya dimulai ketika di langit telah hilang mega merah, dan waktu Subuh ketika terbit fajar $^{2}$ (Butar-butar, 2016). Untuk mengetahui awal waktu salat Zuhur,

\footnotetext{
${ }^{1}$ Ismail. 2015. Metode Penentuan Awal Waktu Salat Dalam Perspektif Ilmu Falak. Jurnal Ilmiah Islam Futura, 73-92.

2 Butar-Butar, A. J. 2016. Khazanah Astronomi Islam Abad Pertengahan. Purwokerto: UM Purwokerto Press.
}

Asar, dan Maghrib dapat dilakukan dengan melihat posisi Matahari secara langsung. Namun, untuk ibadah salat Subuh dan isya tidak dapat dilakukan pengamatan posisi Matahari secara langsung karena posisi Matahari berada di bawah horizon dan Matahari tidak dapat dilihat oleh mata. Salat Subuh dan salat Isya merupakan salat yang waktunya mengacu pada awal dan akhir astronomical twilight (fajar astronomi) ${ }^{3}$ (Nor \& Zainuddin, 2012).

Di Indonesia khususnya menjelang puasa dan hari raya sering terjadi perbedaan dan perdebatan seputar hisab dan rukyat dalam menentukan hilal awal bulan hijriah. Persoalan ini bila dipandang secara teknis ilmiah sebenarnya tergolong mudah karena merupakan bagian ilmu eksakta. Tetapi dalam penerapannya di masyarakat tidak sederhana, karena menyangkut faktor-faktor non-eksakta seperti perbedaan pandangan hukum (mazhab dan fikih) $^{4}$ (Raisal, 2018).

${ }^{3}$ Nor, S. A., \& Zainuddin, M. Z. 2012. Sky Brightness for Determination of Fajr and Isha Prayer by Using Sky Quality Meter. International Journal of Scientific \& Engineering Research, 1-3.

${ }^{4}$ Raisal, A. Y. 2018. Berbagai Konsep Hilal di Indonesia. Al-Marshad: Jurnal Astronomi Islam dan Ilmu-Ilmu Berkaitan, 146155 


\section{AL-MARSHAD: JURNAL ASTRONOMI ISLAM DAN ILMU-ILMU BERKAITAN \\ ISSN 2442-5729 (print) || ISSN 2598-2559 (online) \\ http://jurnal.umsu.ac.id/index.php/almarshad \\ DOI: 10.30596/jam.v5i1.3121 || Vol. 5, No. 1 Juni 2019}

Namun dalam menentukan waktu salat jarang terjadi perdebatan tentang penggunaan hisab dan rukyat. Umat islam di Indonesia sehari-hari menggunakan jadwal salat yang dibuat menggunakan metode hisab. Hal ini memudahkan umat islam sehingga umat islam saat ini tidak perlu lagi melihat posisi matahari untuk melaksanakan salat fardu.

Penelitian ini hanya berfokus untuk mengetahui awal waktu salat Subuh karena beberapa tahun ini waktu Subuh menjadi perbincangan dikalangan ulama dan ilmuan Islam di Indonesia. Hal ini dipicu oleh tulisan Syekh Mamduh dari Mesir yang mengatakan bahwa waktu salat Subuh di Indonesia terlalu cepat. Mengenai waktu salat Subuh, Allah swt berfirman dalam Alquran surah Al-Baqarah ayat 187.

"... dan makan minumlah hingga terang bagimu benang putih dari benang hitam, yaitu fajar" (AlBaqarah: 187).

Fajar dalam ayat tersebut menunjukkan waktu untuk mulai berpuasa sekaligus menunjukkan awal waktu salat Subuh. Selanjutnya, fajar tersebut dijelaskan dalam hadis dari Jabir.
"Fajar ada dua macam, pertama melarang makan, tetapi membolehkan salat, yaitu yang terbit melintang di ufuk. Lainnya, fajar yang melarang salat (Subuh), tetapi membolehkan makan, yaitu fajar seperti ekor serigala" (HR. Hakim, Baihaqi dan Daraquthini) ${ }^{5}$ (Hakim, 2017).

Jika waktu salat Subuh di Indonesia terlalu cepat daripada waktu yang seharusnya, maka umat Islam di Indonesia melaksanakan salat ketika waktu yang dilarang untuk salat. Hal tersebut menunjukkan bahwa penelitian ini sangat penting untuk dilakukan.

Dalam ilmu falak, fajar dibagi menjadi dua yaitu fajar shadiq dan fajar kadzib. Para ulama sepakat bahwa awal waktu salat Subuh adalah ketika fajar shadiq. Fajar shadiq dipahami sebagai awal fajar astronomi, cahaya ini muncul di horizon timur menjelang terbit Matahari ketika Matahari berada sekitar $18^{\circ}$ di bawah horizon ${ }^{6}$ Untuk mengetahui awal waktu Subuh pada saat Matahari berada di bawah horizon maka dapat dihitung dengan mengukur tingkat kecerahan langit.

${ }^{5}$ Hakim, S. A. 2017. Kontroversi Awal Waktu Shalat Subuh. Materi Seminar Model Integrasi Sains-Islam (hal. 3-12). Jakarta: ISRN UHAMKA.

6 Tim Majelis Tarjih dan Tajdid PP Muhammadiyah. (2009). Pedoman Hisab Muhammadiyah. Yogyakarta: Majelis Tarjih dan Tajdid PP Muhammadiyah. 


\section{AL-MARSHAD: JURNAL ASTRONOMI ISLAM DAN ILMU-ILMU BERKAITAN \\ ISSN 2442-5729 (print) || ISSN 2598-2559 (online) \\ http://jurnal.umsu.ac.id/index.php/almarshad \\ DOI: 10.30596/jam.v5i1.3121 || Vol. 5, No. 1 Juni 2019}

Tingkat kecerahan langit bisa dikuantifikasi dengan menggunakan alat Sky Quality Meter (SQM). Dengan memanfaatkan SQM, tingkat kecerahan langit bisa diukur secara obyektif ${ }^{7}$. SQM juga dapat digunakan untuk mengukur tingkat polusi cahaya di suatu tempat $^{8}$. SQM merupakan alat fotometer sederhana yang relatif murah, ringan, dan berukuran saku dengan tingkat kesalahan kurang dari $3 \%{ }^{9}$. Penentuan waktu salat Subuh menggunakan SQM dapat dipengaruhi oleh nilai deklinasi matahari, cuaca, dan permukaan tempat pengamatan ${ }^{10}$. Selain itu, fase bulan juga dapat mempengaruhi tingkat kecerahan langit yang terbaca $\mathrm{SQM}^{11}$. Hasil pengukuran

7 Romadon. 2015. Tesis: Verifikasi Hisab Awal Salat Magrib, Isya Dan Subuh Menggunakan Sky Quality Meter Dan Aplikasinya Pada Mata Kuliah Astronomi. Yogyakarta: Magister PFIS Universitas Ahmad Dahlan.

${ }^{8}$ Pun, C. S., So, C. W., \& Wong, C. F. 2012. The Night Sky Monitoring Network in Hong Kong. Highlights of Astronomy, 16.

${ }^{9}$ Herdiwijaya, D., \& Arumaningtyas, E. P. 2011. Pengukuran Kecerahan Langit Arah Zenith di Bandung dan Cimahi Menggunakan Sky Quality Meter. Prosidings Seminar Himpunan Astronomi Indonesia, 6-8.

${ }^{10}$ Ahyar, M., Pramudya Y., Raisal A. Y, \& Okimustava. 2018. Penentuan Awal Waktu Subuh Menggunakan Sky Quality Meter pada Variasi Deklinasi Matahari. Prosiding SNFA (Seminar Nasional Fisika dan Aplikasinya), 184-189.

11 Raisal A. Y, Pramudya Y., Okimustava, \& Muchlas. 2017. The Moon tingkat kecerahan langit menggunakan SQM digunakan sebagai instrumen astronomi untuk memverifikasi hisab salat ketika Matahari tidak bisa diamati secara langsung karena Matahari masih di bawah horizon.

Data yang didapat dari SQM dibuat grafik sehingga terlihat peralihan dari malam menuju pagi. Semakin gelap langit maka tingkat kecerahannya semakin tinggi, begitu pula sebaliknya. Karena beberapa faktor yang mempengaruhi tingkat kecerahan langit mengakibatkan kurva yang dihasilkan memiliki banyak noise. Untuk mengurangi noise tersebut digunakan metode moving average. Metode moving average merupakan sebuah metode yang sering digunakan dalam analisis teknis yang menunjukkan nilai rata-rata selama periode yang ditetapkan $^{12}$. Semakin sedikit noise yang dihasilkan maka semakin mudah menentukan waktu ketika terjadi awal peralihan dari malam ke pagi hari. Awal

Phases Influence on the Beginning of Astronomical Dawn Determination in Yogyakarta. International Journal of Science and Applied Science: Conference Series, 1-7.

12 Abbas, I. 2016. Penerapan Metode Moving Average (MA) Berbasis Algoritma Support Vector Machine (SVM) untuk Membandingkan Pola Kurva dengan Trend Kurpa pada Trending Forex Online. Jurnal Ilmiah ILKOM Volume 8 Nomor 1, 37-43. 


\section{AL-MARSHAD: JURNAL ASTRONOMI ISLAM DAN ILMU-ILMU BERKAITAN \\ ISSN 2442-5729 (print) || ISSN 2598-2559 (online) \\ http://jurnal.umsu.ac.id/index.php/almarshad \\ DOI: 10.30596/jam.v5i1.3121 || Vol. 5, No. 1 Juni 2019}

peralihan dari malam ke pagi tersebut didefinisikan sebagai awal waktu Subuh.

\section{B. Waktu salat Subuh}

Salat merupakan rukun Islam kedua karena itu merupakan salah satu bentuk ibadah yang amat penting. Para ulama mengatakan bahwa salat merupakan tiang agama. Barang siapa yang menegakkannya berarti menegakkan agama dan barang siapa yang meruntuhkannya berarti meruntuhkan agama. Mengingat pentingnya salat dalam agama Islam, maka ibadah ini tentu harus menjadi perhatian sungguh-sungguh umat Islam, termasuk memperhatikan waktu-waktu pelaksanaanya.

Waktu salat Subuh dikatakan dalam alquran surah Al-Baqarah ayat 187.

"...dan makan minumlah hingga terang bagimu benang putih dari benang hitam, yaitu fajar” (Al-Baqarah: 187).

Selain dari Alquran, terdapat beberapa hadis Nabi saw yang menjelaskan tentang waktu pelaksanaan salat Subuh. Salah satunya adalah hadis yang diriwayatkan oleh Muslim. "...dan waktu salat Subuh adalah dari terbit fajar sampai sebelum Matahari terbit ..." [HR Muslim].

Hadis lain yang juga menjelaskan waktu pelaksanaan salat Subuh adalah hadis yang diriwayatkan oleh Ibn Hibban.

“...Kemudian Jibril datang lagi kepada Nabi saw ketika fajar menyingsing memulai Subuh dan berkata: Berdirilah wahai Muhammad dan kerjakan salat (Subuh). Maka Nabi saw berdiri dan mengerjakan salat Subuh ...Kemudian Jibril datang lagi kepada Nabi saw pada waktu Subuh ketika Subuh itu sudah sangat terang dan berkata: Berdirilah dan kerjakan salat Subuh. Maka Nabi saw berdiri dan mengerjakan salat Subuh. Kemudian ia berkata: Waktu antara kedua waktu itu seluruhnya adalah waktu salat" [HR Ibn Hibban dalam sahihnya. Hadis senada juga diriwayatkan oleh anNasa'i dan beberapa ahli hadis lainnya $]^{13}$.

Dari ayat Alquran dan hadis tersebut dapat disimpulkan bahwa waktu salat Subuh dimulai ketika terbit fajar sampai terbit Matahari.

Dalam ilmu falak, fajar dibedakan menjadi dua yaitu fajar shadiq (nyata)

13 Tim Majelis Tarjih dan Tajdid PP Muhammadiyah. (2009). Pedoman Hisab Muhammadiyah. Yogyakarta: Majelis Tarjih dan Tajdid PP Muhammadiyah. 


\section{AL-MARSHAD: JURNAL ASTRONOMI ISLAM DAN ILMU-ILMU BERKAITAN \\ ISSN 2442-5729 (print) || ISSN 2598-2559 (online) \\ http://jurnal.umsu.ac.id/index.php/almarshad \\ DOI: 10.30596/jam.v5i1.3121 || Vol. 5, No. 1 Juni 2019}

dan fajar kadzib (semu). Fajar shadiq didefinisikan sebagai cahaya yang tampak dan menyebar di atas horizon timur. Fajar kadzib didefinisikan sebagai cahaya yang menjulang ke atas pada posisi tengah-tengah langit dan memiliki bentuk seperti ekor serigala. Fajar kadzib terbit sebelum terbitnya fajar shadiq dan bersifat sementara sebelum menghilang kembali. Dalam astronomi fajar kadzib disebut sebagai cahaya zodiak. Para ulama sepakat bahwa awal waktu Subuh mulai ketika terbit fajar shadiq sampai terbit Matahari $^{14}$.

Dalam astronomi, fajar dibedakan menjadi tiga berdasarkan ketinggian Matahari di bawah horizon, yaitu fajar astronomi, fajar nautikal, dan fajar sipil. Pada saat ketinggian Matahari 18 derajat sampai 12 derajat dibawah horizon, fajar ini dinamakan fajar astronomi (astronomical twilight). Pada saat fajar astronomi, langit sudah gelap sehingga benda-benda di sekitar tidak dapat dibedakan kecuali mata sudah beradaptasi cukup lama dalam kegelapan. Fajar nautikal (nautical twilight) terjadi pada saat ketinggian

14 Mughits, A. 2014. Problematika Jadwal Waktu Salat Subuh di Indonesia. Jurnal Ilmu Syariah dan Hukum, 467-487.
Matahari berada pada 12 derajat sampai 6 derajat dibawah horizon. Pada saat fajar nautikal, langit masih cukup gelap atau remang-remang sehingga batas horizon di pantai dan awan tidak terlihat jelas. Fajar sipil (civil twilight) terjadi bila ketinggian Matahari berada pada 6 derajat dibawah horizon sampai horizon. Ciri fajar sipil adalah hamburan cahaya Matahari sudah cukup terang, sehingga benda-benda di sekitar dapan dengan mudah dibedakan tanpa membutuhkan bantuan lampu ${ }^{15}$. Gambaran umum fajar dan senja dapat dilihat pada gambar 1 .

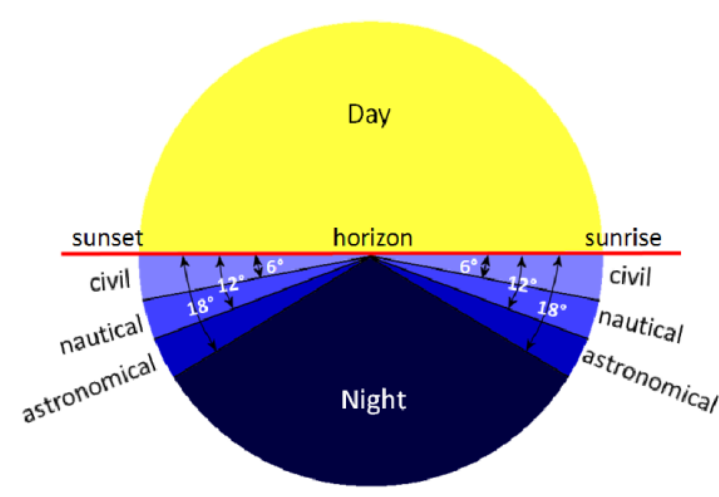

Gambar 1. Gambaran umum senja dan fajar (sumber: https://www.weather.gov)

15 Herdiwijaya, D. 2016. Makalah Narasumber Halaqah Nasional Ahli Hisab dan Fikih Muhammadiyah. Yogyakarta: Majelis Tarjih dan Tajdid Pimpinan Pusat Muhammadiyah. 


\section{AL-MARSHAD: JURNAL ASTRONOMI ISLAM DAN ILMU-ILMU BERKAITAN \\ ISSN 2442-5729 (print) || ISSN 2598-2559 (online) \\ http://jurnal.umsu.ac.id/index.php/almarshad \\ DOI: 10.30596/jam.v5i1.3121 || Vol. 5, No. 1 Juni 2019}

Negara Indonesia yang diwakili oleh Kementerian Agama menetapkan ketinggian Matahari 20 derajat di bawah horizon dalam menentukan awal waktu salat Subuh. Tidak hanya di Indonesia, perbedaan dalam menentukan ketinggian Matahari juga terjadi di negara-negara yang terdapat umat Islam. Perbedaan ketinggian Matahari dalam menentukan waktu Subuh di beberapa negara dapat dilihat pada tabel 1.

Tabel 1 Ketinggian Matahari dalam menentukan awal waktu salat Subuh di beberapa negara ${ }^{16}$

\begin{tabular}{|c|c|c|}
\hline No & Konvensi & $\begin{array}{c}\text { Ketinggian } \\
\text { Matahari }\end{array}$ \\
\hline 1 & $\begin{array}{l}\text { Shiah Ithna Ashari } \\
\text { (Jaafari) }\end{array}$ & $-16^{\circ}$ \\
\hline 2 & $\begin{array}{lr}\text { Islamic } & \text { Society of } \\
\text { North } & \text { America } \\
\text { (ISNA) } & \end{array}$ & $-15^{\circ}$ \\
\hline 3 & $\begin{array}{l}\text { Muslim World } \\
\text { League (MWL) }\end{array}$ & $-18^{\circ}$ \\
\hline 4 & $\begin{array}{ll}\text { Umm } & \text { Al-qura } \\
\text { Makkah } & \end{array}$ & $-18,5^{\circ}$ \\
\hline 5 & $\begin{array}{l}\text { Eqyptian General } \\
\text { Authority of Survey }\end{array}$ & $-19,5^{\circ}$ \\
\hline 6 & $\begin{array}{lr}\text { University } & \text { of } \\
\text { Islamic } & \text { Science, } \\
\text { Karachi } & \end{array}$ & $-18^{\circ}$ \\
\hline 7 & Malaysia & $-20^{\circ}$ \\
\hline
\end{tabular}

16 Nor, S. A., \& Zainuddin, M. Z. 2012. Sky Brightness for Determination of Fajr and Isha Prayer by Using Sky Quality Meter. International Journal of Scientific \& Engineering Research, 1-3.

\section{Sky Quality Meter (SQM)}

Sky Quality Meter (SQM) adalah alat yang digunakan untuk mengukur pencahayaan dari langit malam dengan ukuran saku dan harga yang murah seperti terlihat pada gambar 2. Alat ini memungkinkan bagi masyarakat umum untuk mengukur kualitas langit malam kapanpun dan dimanapun ${ }^{17}$. SQM juga dapat digunakan untuk mengetahui polusi cahaya suatu tempat dan interaksi awal gerhana Matahari $^{18}$. SQM mengukur kecerahan langit malam dalam bentuk magnitudo per detik busur persegi (MPSAS) atau secara matematika dapat ditulis mag/arcsec ${ }^{2}$. Magnitudo adalah satuan atronomi untuk mengukur tingkat kecerahan suatu benda. Satu detik busur adalah luas suatu persegi busur langit yang sisi-sisinya adalah satu detik busur. Semakin tinggi nilai yang terbaca SQM maka semakin gelap benda tersebut. Setiap perubahan $5 \mathrm{mag} / \operatorname{arcsec}^{2}$ berarti langit 100 kali lebih cerah. Berbagai

17 Cinzano, P. 2005. Night Sky Photometry with Sky Quality Meter. STIL Internal Report, 1-14.

18 Pramudya, Y., \& Arkanuddin, M. 2016. The Sky Brightness Measurement During the 2016. Journal of Physics: Conference Series 771, 1-4. 


\section{AL-MARSHAD: JURNAL ASTRONOMI ISLAM DAN ILMU-ILMU BERKAITAN \\ ISSN 2442-5729 (print) || ISSN 2598-2559 (online) \\ http://jurnal.umsu.ac.id/index.php/almarshad \\ DOI: 10.30596/jam.v5i1.3121 || Vol. 5, No. 1 Juni 2019}

faktor dapat menyebabkan kecerahan langit malam berubah-ubah. Pengambilan banyak data akan sangat berguna dalam mengesampingkan kejadian sesaat selama proses pengambilan data. SQM mengumpulkan cahaya sedikitnya dalam satu detik, dan hasil yang diperoleh didasarkan pada cahaya yang terakumulasi selama waktu tersebut. Faktor yang mempengaruhi SQM dalam pengumpulan cahaya adalah polusi cahaya buatan manusia (lampu jalan, gedung perkantoran, dll), cahaya Bulan, aurora, airglow, cahaya galaksi Bima Sakti, kelembaban, erupsi merapi, dan

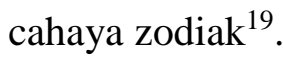

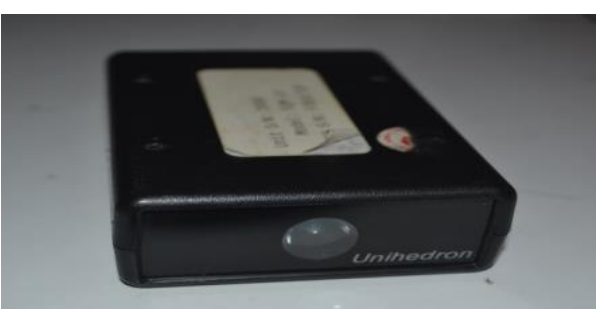

Gambar 2. Tampilan dari SQM

\section{Moving Average}

Data kecerahan langit yang terekam oleh SQM tidak dapat terlepas dari noise yang dapat disebabkan oleh beberapa faktor seperti petir, komet, meteor, sumber cahaya lainnya dan

${ }^{19}$ Unihedron. 2011. SQM-LU Operator's Manual. http://unihedron.com. pergerakan awan di lokasi pengamatan. Metode moving average digunakan untuk memperhalus noise yang diperoleh oleh data sehingga perubahan kecerahan langit yang terjadi dapat diidentifikasi secara lebih jelas.

Metode moving average merupakan sebuah metode yang sering digunakan dalam analisis teknis yang menunjukkan nilai rata-rata selama periode yang ditetapkan. Data yang dirata-ratakan merupakan data yang bergantung waktu (time series). Metode moving average dapat digunakan untuk membuat kurva yang halus atau smooth dan menyaring noise data sehingga lebih mudah untuk melihat trend data tersebut ${ }^{20}$. Metode moving average dapat dirumuskan sebagai berikut:

$$
A_{t}=\frac{D_{t}+D_{t-1}+D_{t-2}+\ldots+D_{t-N+1}}{N}
$$

Dengan

$\mathrm{A}_{\mathrm{t}}=$ prediksi pada periode $\mathrm{t}+1$

$\mathrm{D}_{\mathrm{t}}=$ data rentet waktu

$\mathrm{N}=$ total jumlah periode rataan

20 Abbas, I. 2016. Penerapan Metode Moving Average (MA) Berbasis Algoritma Support Vector Machine (SVM) untuk Membandingkan Pola Kurva dengan Trend Kurpa pada Trending Forex Online. Jurnal Ilmiah ILKOM Volume 8 Nomor 1, 37-43. 


\section{AL-MARSHAD: JURNAL ASTRONOMI ISLAM DAN ILMU-ILMU BERKAITAN \\ ISSN 2442-5729 (print) || ISSN 2598-2559 (online) \\ http://jurnal.umsu.ac.id/index.php/almarshad \\ DOI: 10.30596/jam.v5i1.3121 || Vol. 5, No. 1 Juni 2019}

\section{E. Pembahasan}

Pengambilan data dilakukan dengan cara menghubungkan SQM dengan komputer atau laptop menggunakan kabel USB kemudian diarahkan ke langit arah zenit tanpa ada yang mengalangi muka SQM. Data kecerahan langit dikumpulkan menggunakan aplikasi Unihedron Device Manager (UDM) dan diambil setiap 5 detik dari pukul 3 pagi hingga nilai SQM menunjukkan nilai nol. Selanjutnya data diolah menggunakan moving average yang tersedia di aplikasi Microsoft Excel.

Data pengamatan yang dihasilkan melalui SQM berupa waktu pengamatan, suhu, frekuensi dan tingkat kecerahan langit dalam bentuk file dat. Sekali pengambilan data sekitar tiga jam dapat menghasilkan hingga dua ribu data. Hal ini dikarenakan SQM diatur untuk mengambil data setiap 5 detik. Hasil pengamatan yang berupa file dat tersebut kemudian diolah menggunakan Microsoft Excel untuk mengambil data yang dibutuhkan yaitu waktu dan tingkat kecerahan langit.

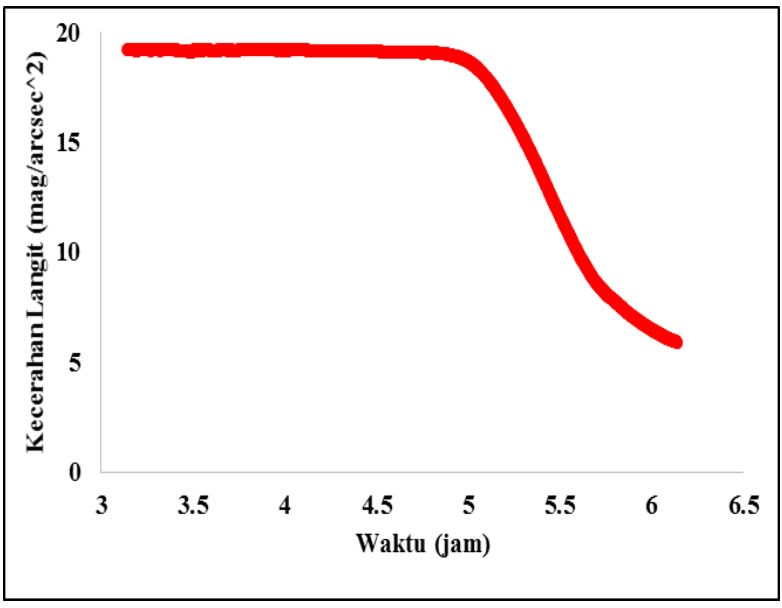

Gambar 3. Grafik tingkat kecerahan langit terhadap waktu tanggal 13 Juni 2016

Gambar 3 merupakan grafik tingkat kecerahan langit (mag/arcsec ${ }^{2}$ ) terhadap waktu (jam) yang diambil pada tanggal 13 Juni 2016. Dari gambar 3 dapat dilihat nilai kecerahan langit yang diperoleh relatif konstan untuk beberapa waktu. Nilai kecerahan langit yang konstan menunjukkan bahwa langit masih gelap atau malam. Lalu pada saat tertentu mulai terjadi penurunan nilai kecerahan langit secara bertahap. Hal ini disebabkan cahaya Matahari mulai menyinari atmosfer bumi meskipun Matahari masih di bawah horizon sehingga nilai kecerahan langit berubah. Pada saat ini dianggap sebagai terbit fajar atau menunjukkan awal waktu salat Subuh. Namun untuk menentukan kapan tepatnya waktu salat Subuh sangat sulit ditentukan dengan hanya menggunakan cara tersebut. 


\section{AL-MARSHAD: JURNAL ASTRONOMI ISLAM DAN ILMU-ILMU BERKAITAN \\ ISSN 2442-5729 (print) || ISSN 2598-2559 (online) \\ http://jurnal.umsu.ac.id/index.php/almarshad \\ DOI: 10.30596/jam.v5i1.3121 || Vol. 5, No. 1 Juni 2019}

Untuk mempermudah dalam menentukan waktu salat Subuh maka dicari selisih antara data kecerahan langit. Kemudian dengan menggunakan analysis tools dari Microsoft Excel dibuat rata-rata menggunakan moving average terhadap selisih yang diperoleh. Interval yang digunakan pada moving average adalah 6 data. Kemudian dibuat grafik antara data moving average dengan waktu pengamatan. Grafik selisih kecerahan langit terhadap waktu menggunakan moving average dapat dilihat pada gambar 4 .

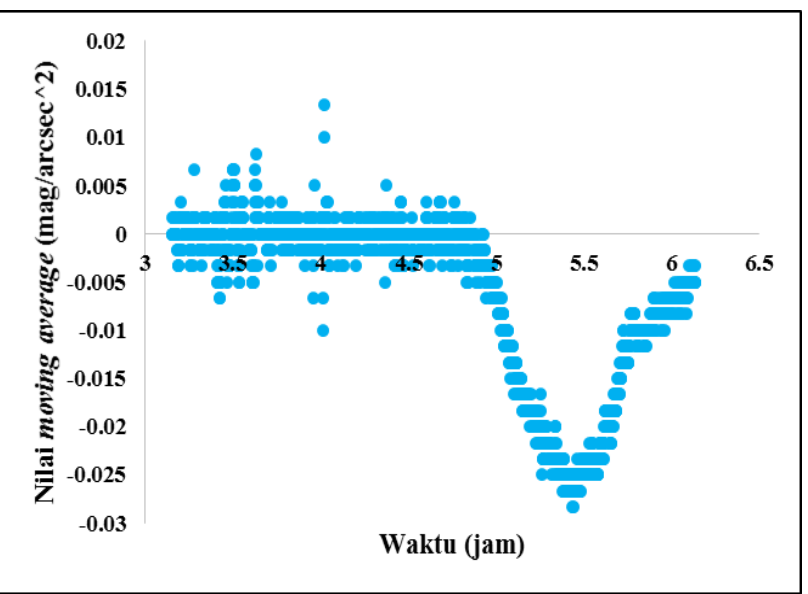

Pada gambar 4 dapat dilihat pada waktu tertentu nilai moving average secara bertahap menurun atau nilai minus yang diperoleh semakin besar. Setelah turun secara bertahap, nilai tersebut naik kembali secara bertahap mendekati nilai nol. Hal ini disebabkan terjadi perlambatan dalam proses perubahan kecerahan langit. Walaupun nilai kecerahan langit yang diperoleh semakin kecil namun selisih yang diperoleh semakin kecil. Waktu pada saat nilai nol terakhir pada selisih kecerahan langit ditentukan sebagai waktu salat Subuh berdasarkan pengukuran $\left(t_{u k u r}\right)$ seperti terlihat pada gambar 5. Garis merah pada gambar 5 menunjukkan nilai nol terakhir pada selisih kecerahan langit. Waktu yang sesuai dengan garis merah tersebut kemudian ditentukan sebagai $t_{u k u r}$.

Gambar 4. Grafik selisih kecerahan langit menggunakan moving average terhadap waktu 


\section{AL-MARSHAD: JURNAL ASTRONOMI ISLAM DAN ILMU-ILMU BERKAITAN}

ISSN 2442-5729 (print) || ISSN 2598-2559 (online)

http://jurnal.umsu.ac.id/index.php/almarshad

DOI: 10.30596/jam.v5i1.3121 || Vol. 5, No. 1 Juni 2019

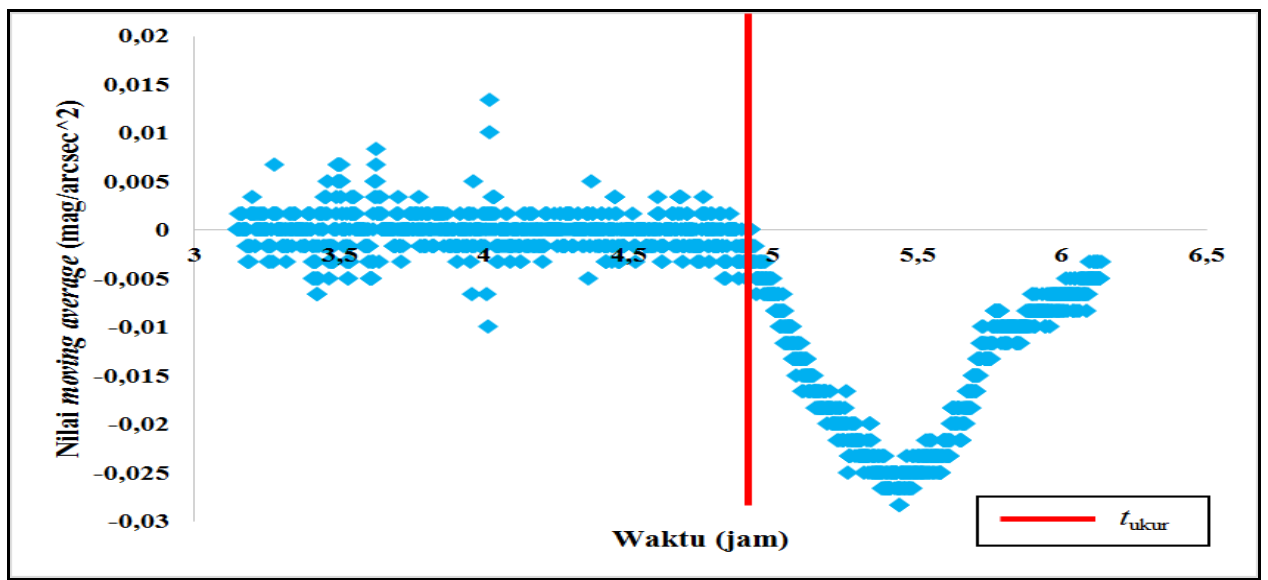

Gambar 5. Waktu salat Subuh berdasarkan pengukuran

\section{F. Kesimpulan}

\section{Daftar Pustaka}

Berdasarkan data-data hasil penelitian dan pembahasan yang telah dilakukan maka dapat diambil kesimpulan sebagai berikut:

1. Terdapat perbedaan dibeberapa negara tentang ketinggian Matahari yang digunakan dalam menentukan awal waktu salat Subuh. Indonesia menggunakan ketinggian Matahari $20^{\circ}$ di bawah horizon dalam menentukan awal waktu Subuh.

2. Banyak faktor yang dapat mempengaruhi SQM dalam pengumpulan cahaya sehingga data yang dihasilkan tidak terlepas dari noise. Penggunaan metode moving average dapat mengurangi noise sehingga memudahkan dalam menentukan awal waktu salat Subuh menggunakan SQM.

Abbas, I. 2016. Penerapan Metode

Moving Average (MA) Berbasis Algoritma Support Vector Machine (SVM) untuk Membandingkan Pola Kurva dengan Trend Kurpa pada Trending Forex Online. Jurnal Ilmiah ILKOM Volume 8 Nomor 1, 37-43.

Ahyar, M., Pramudya Y., Raisal A. Y, \& Okimustava. 2018. Penentuan Awal Waktu Subuh Menggunakan Sky Quality Meter pada Variasi Deklinasi Matahari. Prosiding SNFA (Seminar Nasional Fisika dan Aplikasinya), 184-189.

Butar-Butar, A. J. 2016. Khazanah Astronomi Islam Abad 


\section{AL-MARSHAD: JURNAL ASTRONOMI ISLAM DAN ILMU-ILMU BERKAITAN \\ ISSN 2442-5729 (print) || ISSN 2598-2559 (online) \\ http://jurnal.umsu.ac.id/index.php/almarshad \\ DOI: 10.30596/jam.v5i1.3121 || Vol. 5, No. 1 Juni 2019}

Pertengahan. Purwokerto: UM

Purwokerto Press.

Butar-Butar, A. J. 2017. Waktu Shalat

Menurut Sejarah Fikih dan

Astronomi. Malang: Madani.

Cinzano, P. 2005. Night Sky

Photometry with Sky Quality

Meter. STIL Internal Report, 114.

Hakim, S. A. 2017. Kontroversi Awal

Waktu Shalat Subuh. Materi

Seminar Model Integrasi Sains-

Islam (hal. 3-12). Jakarta: ISRN

UHAMKA.

Herdiwijaya, D. 2016. Makalah

Narasumber Halaqah Nasional

Ahli Hisab dan Fikih

Muhammadiyah. Yogyakarta:

Majelis Tarjih dan Tajdid

Pimpinan Pusat Muhammadiyah.

Herdiwijaya, D., \& Arumaningtyas, E.

P. 2011. Pengukuran Kecerahan

Langit Arah Zenith di Bandung

dan Cimahi Menggunakan Sky

Quality Meter. Prosidings

Seminar Himpunan Astronomi

Indonesia, 6-8.

Ismail. 2015. Metode Penentuan Awal

Waktu Salat Dalam Perspektif

Ilmu Falak. Jurnal Ilmiah Islam

Futura, 73-92.
Mughits, A. 2014. Problematika Jadwal Waktu Salat Subuh di Indonesia. Jurnal Ilmu Syariah dan Hukum, 467-487.

Nor, S. A., \& Zainuddin, M. Z. 2012. Sky Brightness for Determination of Fajr and Isha Prayer by Using Sky Quality Meter. International Journal of Scientific \& Engineering Research, 1-3.

Pramudya, Y., \& Arkanuddin, M. 2016. The Sky Brightness Measurement During the 2016. Journal of Physics: Conference Series 771, 1-4.

Pun, C. S., So, C. W., \& Wong, C. F. 2012. The Night Sky Monitoring Network in Hong Kong. Highlights of Astronomy, 16.

Raisal, A. Y. 2018. Berbagai Konsep Hilal di Indonesia. Al-Marshad: Jurnal Astronomi Islam dan IlmuIlmu Berkaitan, 146-155

Raisal A. Y, Pramudya Y., Okimustava, \& Muchlas. 2017. The Moon Phases Influence on the Beginning of Astronomical Dawn Determination in Yogyakarta. International Journal of Science and Applied Science: Conference Series, 1-7. 


\section{AL-MARSHAD: JURNAL ASTRONOMI ISLAM DAN ILMU-ILMU BERKAITAN}

ISSN 2442-5729 (print) || ISSN 2598-2559 (online)

http://jurnal.umsu.ac.id/index.php/almarshad

DOI: 10.30596/jam.v5i1.3121 || Vol. 5, No. 1 Juni 2019

Romadon. 2015. Tesis: Verifikasi Hisab

Awal Salat Magrib, Isya Dan

Subuh Menggunakan Sky Quality

Meter Dan Aplikasinya Pada

Mata Kuliah Astronomi.

Yogyakarta: Magister PFIS

Universitas Ahmad Dahlan.

Tim Majelis Tarjih dan Tajdid PP

Muhammadiyah. (2009).

Pedoman Hisab Muhammadiyah.

Yogyakarta: Majelis Tarjih dan

Tajdid PP Muhammadiyah.

Unihedron. 2011. SQM-LU Operator's

Manual. http://unihedron.com. 